\title{
Penerapan Metode Waterfall Dan Webqual 4.0 Pada Pengembangan Website Dealer Asa Mandiri Motor
}

\author{
http://dx.doi.org/10.28932/jutisi.v5i2.1729
}

\author{
Meldy Saimon Pinontoan ${ }^{\bowtie \# 1}$, Antonius Rachmat ${ }^{* 2}$, Rosa Delima ${ }^{\# 3}$ \\ \# Informatika, Universitas Kristen Duta Wacana \\ Jl. Dr. Wahidin Sudirohusodo No. 5-25, Yogyakarta \\ ${ }^{1} \mathrm{meldy} \cdot \mathrm{pinontoaneti \cdot ukdw \cdot ac \cdot id}$ \\ ${ }^{3}$ rosadelimaestaff.ukdw.ac.id \\ * Informatika, Universitas Kristen Duta Wacana \\ Jl. Dr. Wahidin Sudirohusodo No. 5-25, Yogyakarta \\ 2 antoneti.ukdw.ac.id
}

\begin{abstract}
Asa Mandiri Motor Dealer is one of the companies involved in the sale and purchase of used motorcycles. The problem that occurs at Asa Mandiri Motor Dealer is the decline in customer visits due to the lack of strategic location of the main dealer. The purpose of establishing a system for developing Asa Mandiri Motor dealer through the Waterfall method website is to measure the quality level using the Webqual 4.0 method and the Importance Performance Analysis (IPA) to determine the assessment tests and improvements that are required to improve the service to users and customers through the website.In this study, the author also tested the waterfall method using black box testing to determine the level of functionality on the site, and using tests on the quality level of the site to make recommendations for improvements through quadrant analysis in the Webqual 4.0 method and the Importance Performance Analysis (IPA). This test was conducted on 50 respondents based on the type of respondent (client, non-client (general public), administrator). The results of the study show that the website can be accessed online. The level of website functionality that meets the design requirements, still has a gap value of $\mathbf{- 0 . 0 7}$, which means that the site is still not in accordance to the needs of users with relatively small scores. The author has made improvements to the indicators (INF1, INF2, INF3, USA4, USA5), but no further testing has been done.
\end{abstract}

Keywords- Waterfall, Webqual 4.0, Importance Analysis, Black Box Test

\section{PENDAHULUAN}

Pada saat ini teknologi informasi semakin berkembang pesat. Banyak usaha yang memanfaatkan teknologi informasi untuk menunjang dan mengembangkan kinerja usahanya. Media online yang berbasis web saat ini sedang diminati para pelaku usaha sebagai faktor pendukung dalam mengembangkan usaha. Website digunakan sebagai media agar masyarakat lebih mudah mendapatkan informasi. Asa Mandiri Motor merupakan salah satu usaha yang bergerak dibidang penjualan dan pembelian sepeda motor bekas yang saat ini sedang berkembang di Yogyakarta, memiliki peningkatan pelanggan setiap tahunnya dan harus dapat bersaing dengan pengusaha jual beli sepeda motor bekas lainnya.

Permasalahan yang terjadi dalam dealer sepeda motor bekas ini adalah mahalnya biaya sewa yang menyebabkan salah satu cabang ditutup dan kurang strategisnya lokasi dealer utama yang masih berjalan. Hal ini menyebabkan menurunnya kunjungan konsumen. Dengan adanya website diharapkan dealer dapat mempublikasikan produk secara lebih luas dan dapat melakukan komunikasi secara timbal balik dengan konsumen. Keuntungan lainnya juga dealer dapat memiliki website sendiri yang meningkatkan kesan profesional dan kepercayaan konsumen dalam menampilkan informasi produk dan layanan. Perancangan website ini akan menggunakan metode waterfall dan diuji kualitasnya menggunakan Webqual 4.0 dan Importance Performance Analysis (IPA).

\section{LANDASAN TEORI}

\section{A. Tinjauan Pustaka}

Pada penelitian Romadhoni, dkk mengenai penggunaan metode waterfall yang membahas perancangan sistem informasi untuk alumni SMK [1]. Alasan mereka menggunakan waterfall model dikarenakan definisi kebutuhan sekolah telah terdefinisi secara jelas. Dari hasil penelitian website alumni SMK, dapat dijadikan referensi juga untuk peneliti agar dapat mencari definisi kebutuhan secara jelas pada dealer Asa Mandiri Motor.

Adapun penelitian yang lain berdasarkan keuntungan dan kelemahan menggunakan metode waterfall ini terdapat pada penelitian yang dilakukan Adewono dkk, keuntungan yang dimiliki oleh metode waterfall ialah menjadi model linier dan terstruktur, sangat mudah diterapkan, dan lebih murah [2]. Kelemahan yang paling jelas dari waterfall adalah ketidakmampuan untuk mengevaluasi hasil dari satu 
tahap sebelum pindah ke yang berikutnya (evaluasi intermiten). Hasil dari penelitian ini menganggap metode waterfall lebih kaku karena pendekatan liniernya, dan mungkin ada sedikit atau kurang kepuasan pengguna karena tidak ada peluang untuk melakukan perubahan pada sistem. Namun, ketika ada permasalahan domain dan kebutuhan sangat jelas dan lugas dengan menggunakan metode waterfall ini dapat dengan mudah diadopsi karena keserderhanaan dan proses sekuensial.

Setelah terbentuknya sebuah website yang menggunakan metode waterfall pada dealer Asa Mandiri Motor maka akan diuji penelitiannya menggunakan metode Webqual 4.0 dan Importance Performance Analysis (IPA).

Salah satu penelitian dalam penggunaan metode Webqual 4.0 dan Importance Performance Analysis (IPA) dapat mengacu pada penelitian yang dilakukan oleh Santoso dan Anwar, tentang Analisis Kualitas Website Menggunakan Metode Webqual dan ImportancePerformance Analysis (IPA) pada Situs Kaskus [3]. Penelitian ini berisi tentang cara menganalisis kualitas suatu website Kaskus dengan adanya dimensi yang terdapat pada Webqual yaitu Usability, Information, dan Service Interaction serta metode Importance-Performance Analysis (IPA). Hasil yang diperoleh dari penelitian ini berdasarkan hasil keseluruhan indikator dari selisih tingkat kinerja dan tingkat kepentingan didapatkan nilai kesenjangan sebesar 0,84 yang berarti hasil yang didapatkan masih kurang puas bagi pengguna. Dengan adanya hasil dari penelitian ini dapat dijadikan referensi oleh peneliti untuk mengukur kualitas website dengan menggunakan metode Webqual dan Importance-Performance Analysis (IPA).

\section{B. Waterfall}

Mengambil kegiatan proses dasar spesifikasi, pengembangan, validasi, dan evolusi dan mewakili mereka sebagai fase proses terpisah seperti spesifikasi kebutuhan, desain perangkat lunak, implementasi, pengujian, dan sebagainya [4].

Berikut ini akan diuraikan tahap-tahap pengembangan perangkat lunak dengan menggunakan metode waterfall [4]:

1. Requirements analysis and definition: Layanan, kendala, dan sasaran sistem dibuat melalui konsultasi dengan pengguna sistem untuk dijadikan sebagai spesifikasi sistem.

2. System and software design: Proses desain sistem mengalokasikan persyaratan ke perangkat keras atau sistem perangkat lunak dengan membangun keseluruhan arsitektur sistem. Desain perangkat lunak melibatkan identifikasi dan menjelaskan abstraksi sistem perangkat lunak fundamental dan hubungan mereka.

3. Implementation and unit testing: Termasuk pengujian serangkaian program atau unit program.

4. Integration and system testing: Masing-masing unit program atau program diintegrasikan dan diuji sebagai sistem yang lengkap untuk memastikan bahwa persyaratan perangkat lunak telah dipenuhi

\section{Analisis Model}

Dalam pengembangan sebuah sistem pada tahapan system and software design diperlukannya sebuah analisis model yang mengacu pada Scenario-based model, Class models, Behavioral models, dan Flow models [5].

1. Scenario-Based Model: Model analisis yang dapat digunakan yaitu use-case diagram, activity diagram, dan swimlane diagram.

2. Class Model: Setiap skenario penggunaan menyiratkan seperangkat "objek" yang dimanipulasi sebagai aktor berinteraksi dengan sistem. Yang digunakan dalam model ini ialah Class Diagram.

3. Behavioral Model: Model yang digunakan ialah Sequence Diagram. Indikasi menunjukkan bagaimana peristiwa menyebabkan transisi dari objek ke objek.

4. Flow Model: Data Flow Diagram (DFD) merupakan salah satu model yang paling sering digunakan. DFD dibutuhkan untuk input-process-output pada sistem. Tahapan DFD dimulai dari konteks diagram, level 0 DFD, level 1, dan level 2.

\section{Black Box Testing}

Black Box Testing berfokus pada spesifikasi fungsional dari perangkat lunak. Tester dapat mendefinisikan kumpulan kondisi input dan melakukan pengetesan pada spesifikasi fungsional program [6]. Black Box Testing cenderung untuk menemukan hal-hal seperti fungsi yang tidak benar atau tidak ada, kesalahan antarmuka (interface errors), kesalahan pada struktur data dan akses basis data, kesalahan performansi (performance errors), dan kesalahan inisialisasi dan terminasi.

\section{E. Equivalence Partitioning}

Equivalence Partitioning adalah metode pengujian black-box yang membagi domain masukan dari suatu program ke dalam kelas data dari mana test case dapat dilakukan [7]. Metode ini berusaha untuk menentukan sebuah test case yang mengungkap kelas-kelas kesalahan, sehingga mengurangi jumlah total test case yang harus dikembangkan.

Desain test case untuk equivalence partitioning didasarkan pada evaluasi terhadap kelas equivalence untuk suatu kondisi masukan. Kelas Equivalance mempresentasikan serangkaian valid atau invalid untuk kondisi masukan.

\section{F. Webqual}

Kualitas website merupakan isu salah satu strategis terhadap komunikasi dengan pelanggan, dan Webqual disusun berdasarkan persepsi pengguna akhir terhadap suatu website [8]. 
Menurut Slabey yang disitir oleh [9] Webqual adalah pengukuran berdasarkan quality function deployment (QFD). Webqual adalah suatu pengukuran untuk mengukur kualitas dari sebuah website berdasarkan instrumeninstrumen penelitian yang dapat dikategorikan kedalam tiga variabel yaitu: usability, information quality, dan service interaction.

Webqual selama ini memiliki iterasi terhadap penyusunan dimensi dan indikator-indikator pertanyaan. Versi terbaru adalah Webqual 4.0 yang memiliki 3 dimensi yaitu Usability, Information Quality, dan Service Interaction yang diukur dengan 22 indikator pertanyaan [3].

\section{G. Importance-Performance Analysis (IPA)}

Importance-Performance Analysis adalah teknik yang digunakan untuk mengidentifikasi atribut-atribut terhadap sebuah pengembangan [10]. Analisis yang digunakan dalam IPA yaitu analisis kesenjangan (gap) dan analisis kuadran [11].

Proses analisis nilai kesenjangan (gap) dapat dihitung dengan mencari nilai selisih antara nilai kinerja (Performance) dan nilai kepentingan (Importance) [3].

Dari pengolahan data dianalisis dan dipahami empat jenis karakteristik kualitas dan dikembangkan tindakan strategis untuk karakteristik kualitas di masing-masing empat kuadran [12].

\section{METODOLOGI PENELITIAN}

Metodologi yang digunakan dalam perancangan sistem pada penelitian yang akan dilakukan ini ialah:

\section{A. Requirement Definition}

Peneliti melakukan pengumpulan data dengan cara melakukan observasi dan wawancara langsung ke pemilik dealer Asa Mandiri Motor dan mengidentifikasi permasalahan yang terjadi untuk membuat sistem yang baru dengan cara melakukan survei penelitian berdasarkan kuesioner yang didapatkan pada metode Webqual 4.0. Kebutuhan lainnya yang perlu diterapkan ialah Functional Requirement, Non-Functional Requirement dan kebutuhan analisis.

1. Functional Requirement: Functional Requirement dapat menggambarkan kebutuhan dari jenis perangkat lunak, pengguna sistem, dan jenis sistem. Penulis menggunakan referensi dari beberapa website dealer motor lainnya untuk mengetahui menu dan fitur yang paling sering untuk digunakan. Hasil dari survei yang didapat, website Asa Mandiri Motor memiliki kelebihan terhadap fitur komentar yang tidak dimiliki oleh website dealer motor lainnya.

2. Non-Functional Requirement: Sistem pada layanan user tidak dapat mengubah isi dari sistem layanan admin, sistem hanya menampilkan enam produk terbaru pada halaman utama user, sistem hanya menyediakan dalam satu bahasa saja, sistem menggunakan perangkat keras dan lunak yang sudah ditentukan oleh peneliti.

3. Analisis Model: Tahapan anlisis sistem yang akan dibuat mengacu pada analisis model yang digunakan untuk menganalisis website. Analisis model terdiri dari Use case diagram yang menjelaskan interaksi antar aktor dengan sistem yang akan dibuat dapat dilihat pada Gambar 2, Data Flow Diagram (DFD) yang dijelaskan pada diagram konteks yang sudah mencakup keseluruhan pada DFD dapat dilihat pada Gambar 3, dan Sequence Diagram yang dibagi menjadi dua jenis yaitu admin dan user. Sequence Diagram pada user yang digunakan penulis ialah komentar atau reply, hubungi kami dan pertanyaan sedangkan untuk Sequence Diagram pada admin yang digunakan penulis yaitu kelola produk, akun, kategori produk dan kontak.

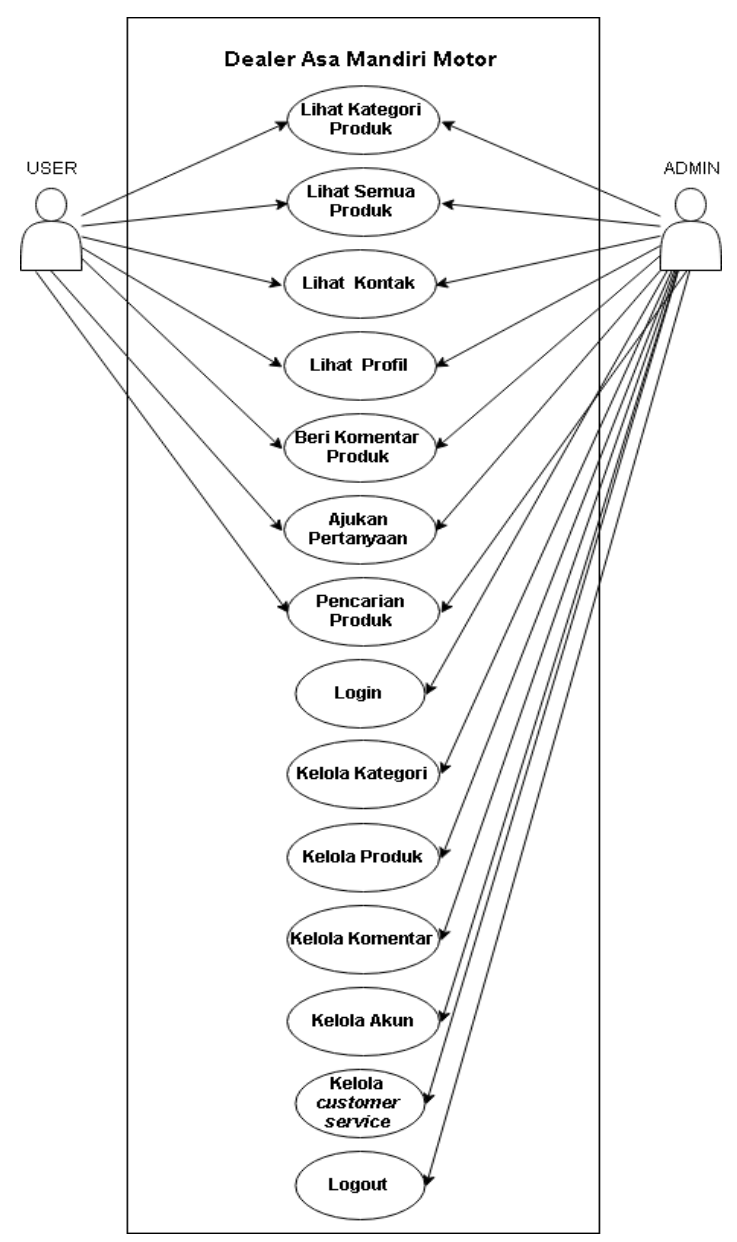

Gambar 1. Use Case Diagram Pengembangan Website Dealer Asa Mandiri

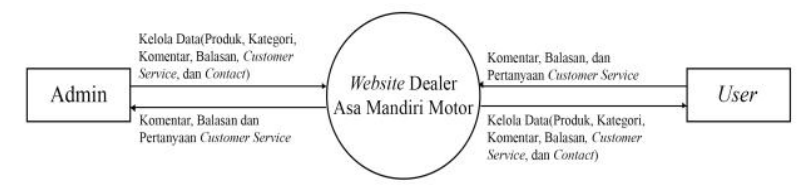

Gambar 2. Diagram Konteks Website Dealer Asa Mandiri Motor Terhadap User dan Admin 


\section{B. System and Software Design}

Setelah tahapan analisis dilanjutkan dengan tahapan desain. Tahapan ini terdiri dari perancangan basis data dan perancangan interface.

1. Perancangan Basis Data: Pada tahap ini dilakukan transformasi dari data manual ke dalam bentuk basis data yang terbagi dalam beberapa tabel, didalamnya terdapat bagian yang dinamakan field. Gambar 4 adalah perancangan skema basis data pada website yang akan dibuat.

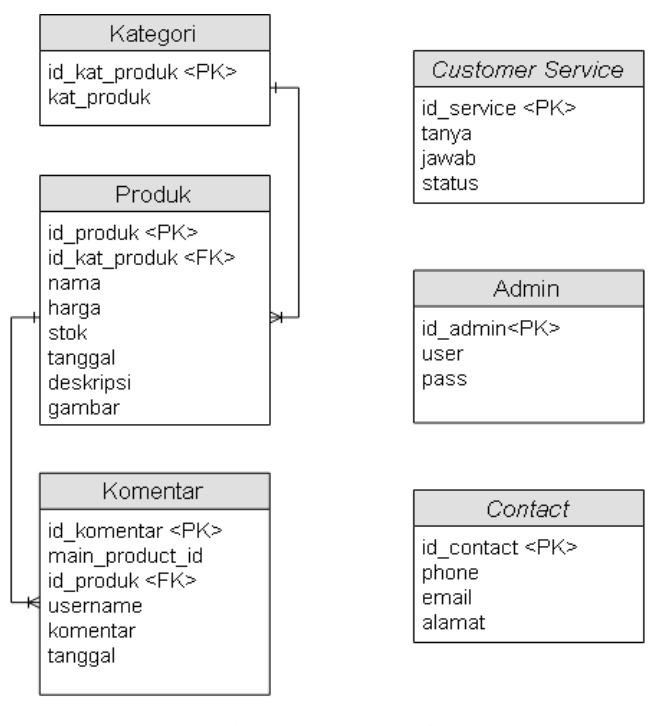

Gambar 3. Skema Basis Data

2. Perancangan Interface: Desain dan implementasi pada penelitian ini, akan menghasilkan gambaran sistem yang sudah dibuat peneliti pada dealer motor bekas Asa Mandiri Motor. Desain yang dibuat sudah dalam bentuk tata letak awal dalam suatu desain yang disebut juga dengan istilah prototype. Perancangan interface user terdiri dari tampilan beranda, detail produk, produk, dan kontak, sedangkan untuk perancangan interface admin berupa tampilan beranda.

\section{Implementation and Unit Testing}

Tahap implementasi dan unit testing dilakukan untuk membuat program berdasarkan hasil analisis dan perancangan yang akan dibuat kedalam bahasa pemrograman. Bahasa pemrograman yang akan digunakan dalam pembuatan website dealer Asa Mandiri Motor antara lain PHP, HTML, dan MySQLI. Tahap inilah yang merupakan pembuatan program dengan cara memasukkan coding kedalam baris-baris yang dapat dimengerti oleh komputer. Setelah terbentuknya website, maka diperlukannya pengujian.

\section{Integration and System Testing}

Pada tahapan ini akan dilakukan pengujian terhadap website yang telah dibuat menggunakan black box testing. Skenario pengujian yang akan penulis susun adalah skenario tugas untuk mengoperasikan website Asa Mandiri Motor sebagai user dan admin.

Hasil dari pengujian menggunakan black box akan dioperasikan dengan melakukan uji evaluasi pada website dealer Asa Mandiri Motor dengan menggunakan Webqual 4.0 sebagai kuisioner yang akan diberikan kepada responden dan diukur tingkat kualitasnya menggunakan ImportancePerformance Analysis (IPA).

1. Variabel Pengujian: Variabel pengujian yang digunakan terdiri dari pengukuran kualitas website menggunakan kuesioner berdasasrkan instrumen Webqual 4.0 dan identifikasi variabel pada pengujian ini berdasarkan tiga dimensi yang dimiliki Webqual 4.0 yaitu dimensi kegunaan sebagai variabel USA (8 pernyataan), kualitas informasi sebagai INF (7 pernyataan) dan interaksi pelayanan sebagai variabel SERV (7 pernyataan)

2. Tahap Pengumpulan Data: Populasi yang digunakan dalam pengujian merupakan pengguna website dikalangan pelanggan, petugas administrasi, dan nonpelanggan (masyarakat umum) yang telah ditentukan minimal 30 responden. Metode pengambilan sampel menggunakan teknik total sampling yaitu teknik pengambilan sampel dimana jumlah sampel sama dengan jumlah populasi [12].

3. Jenis dan Sumber Data: Terbagi menjadi data primer dan data sekunder. Data primer (pelanggan, petugas admin, dan non-pelanggan) yang berpendidikan minimal SMP/SMA, umur minimal 20 tahun, dan dapat mengoperasikan komputer/smarhphone. Data yang diperoleh langsung dari responden melalui penyebaran kuisioner. Kuesioner yang digunakan menggunakan skala likert yang dikategorikan tinggi, cukup tinggi hingga sangat rendah. Untuk mempermudah pengujian dalam melakukan analisis, maka jawaban tersebut dapat di beri skor sebagai berikut. SS (Sangat setuju/tinggi dengan skor 4.20-5.00), S (Setuju/cukup tinggi dengan skor 3.40-4.20), R (Raguragu/sedang dengan skor 2.60-3.40), TS (Tidak setuju/rendah dengan skor 1.80-2.60) dan STS (Sangat tidak setuju/sangat rendah dengan skor 1.00-1.80). Sedangkan untuk data sekunder adalah data yang diperlukan sebagai data pendukung data primer. Data yang diambil pada buku, makalah, jurnal dan data-data pengujian terdahulu. 
4. Analisis Uji Usabilitas: Pada tahapan ini, penulis akan melakukan analisis rekapitulasi kuesioner. Didapatkan dari kuesioner Webqual 4.0 dan mendapatkan skor-skornya berdasarkan rumus kelas interval yang akan dikembangkan lagi dengan menggunakan teknik analisis ImportancePerformace Analysis (IPA) untuk mendapatkan nilai kualitas dari website berupa nilai kesenjangan (gap). Dengan data-data yang diperoleh dari teknik ImportancePerfromance Analysis (IPA) penulis akan mengetahui fiturfitur mana saja yang akan di perbaiki, yang diperlihatkan dalam diagram Importance Performance Matrix. Sedangkan analisis data pada hasil uji skenario akan menghasilkan bagian website mana yang menurut responden kurang memuaskan sehingga dapat mendukung rekomendasi perbaikan.

5. Rekomendasi Perbaikan: Penulis akan memperbaiki website berdasarkan tahapan desain dan impelementasi pada metode waterfall yang telah digunakan.

\section{HASIL DAN ANALISIS}

\section{A. Implementasi Website Asa Mandiri Motor}

Pada tahap implementasi, merupakan tahap kegiatan perancangan website Asa Mandiri Motor yang dibentuk berdasarkan sitemap admin dan sitemap user pada Gambar 4 dan 5.

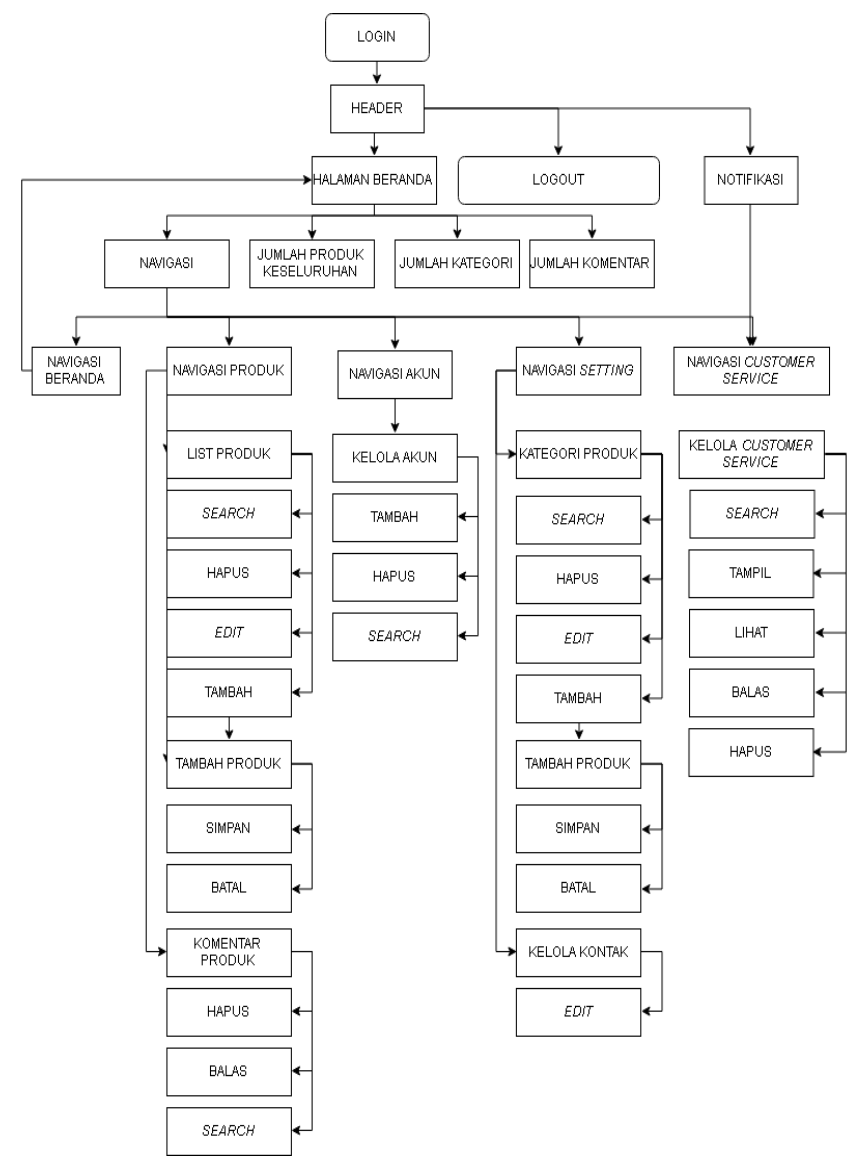

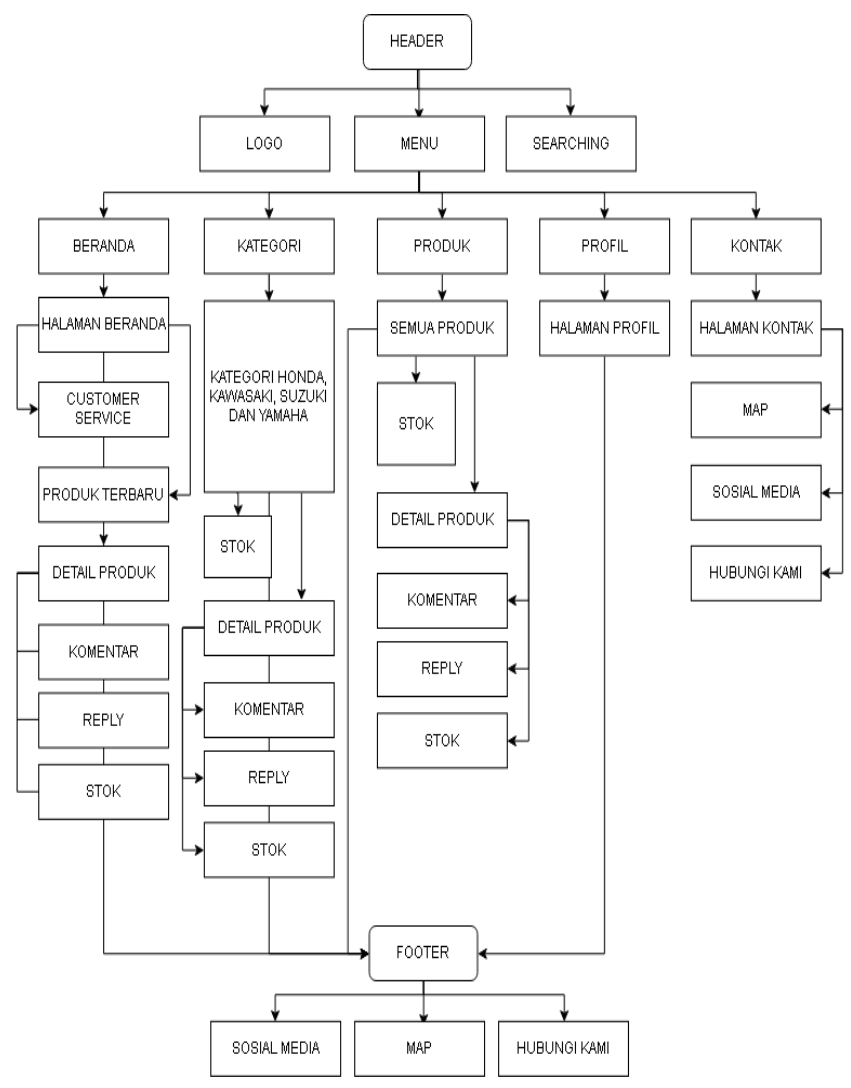

Gambar 5. Sitemap User

Gambar 4 adalah sitemap pengguna yang didapat melalui website dealer Asa Mandiri Motor. Sitemap pengguna ini dimulai dengan adanya header yang memiliki logo, menu, dan pencarian. Logo ketika dipilih akan ke halaman beranda. Pencarian memiliki fungsi dalam mencari produk-produk yang diinginkan. Dan menu terbagi menjadi beberapa jenis yaitu beranda, kategori, produk, profil dan kontak.

Gambar 5 adalah sitemap admin yang diawali admin melakukan login dengan mengisi username dan password. Setelah itu dialihkan ke halaman beranda admin yang setiap halamannya memiliki header dan navigasi. Header memiliki item berupa logout dan notifikasi yang digunakan melihat adanya pertanyaan-pertanyaan masuk melalui customer service. Item navigasi terdiri dari navigasi beranda, produk, akun, setting, dan customer service.

Implementasi fitur dapat dibagi menjadi 9 bagian yaitu fitur pertanyaan, produk terbaru, pencarian, komentar, reply, form hubungi kami, map dan stok.

Implementasi manajemen web hosting, menggunakan cpanel melalui perantara Rumah Web. Instalasi Cpanel sebagai web-hosting penulis memerlukan sebuah perantara Rumahweb yang menyediakan hosting unlimited dan domain yang diinginkan penulis dengan melakukan pembayaran 


\section{B. Pengujian Black Box Tesing}

Pengujian black box testing ini dilakukan oleh penulis untuk mengetahui valid dan invalid berdasarkan kondisi masukan website dealer Asa Mandiri Motor yang dapat dilihat pada Tabel I.

\section{TABEL I FIELD SIAP UJI}

\begin{tabular}{|c|c|c|c|c|c|}
\hline No & Fitur & Field & Elemen & Valid & Invalid \\
\hline 1 & Pencarian & \begin{tabular}{|l|}
1.1 Isi \\
pencarian
\end{tabular} & - Text box & $\begin{array}{l}\text { Keluaran sudah } \\
\text { sesuai dengan } \\
\text { yang dicari }\end{array}$ & $\begin{array}{l}\text { - textbox yang } \\
\text { dikosongkan (1.1, } \\
2.1,3.1,3.2, \text { dan 3.3) }\end{array}$ \\
\hline \multirow[t]{4}{*}{2} & \multirow[t]{4}{*}{$\begin{array}{l}\text { Komentar Baru } \\
\text { dan Reply }\end{array}$} & $\begin{array}{l}2.1 \\
\text { Username } \\
\text { (emain) }\end{array}$ & - Text box & $\begin{array}{l}\text { Adanya masukan } \\
\text { pada textbox }\end{array}$ & \multirow{7}{*}{ 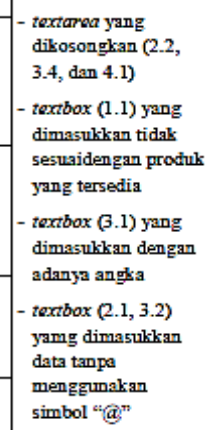 } \\
\hline & & & & & \\
\hline & & \begin{tabular}{|l|}
2.2 Isi \\
Komentar
\end{tabular} & $\begin{array}{l}- \text { Text } \\
\text { area }\end{array}$ & Adanya masukan & \\
\hline & & & & & \\
\hline \multirow[t]{3}{*}{3} & \multirow[t]{3}{*}{ Hubungi Kami } & \begin{tabular}{|l|}
$3.1 \mathrm{Nama}$ \\
$3.2 \mathrm{Email}$
\end{tabular} & - Text box & Adanya masukan & \\
\hline & & 3.3 No.Hp & & & \\
\hline & & 3.4 Isi pesan & $\begin{array}{l}- \text { Text } \\
\text { area }\end{array}$ & $\begin{array}{l}\text { Adanya masukan } \\
\text { pada textarea }\end{array}$ & \\
\hline 4 & \begin{tabular}{|l} 
Customer \\
Service
\end{tabular} & \begin{tabular}{|l|}
4.1 Isi \\
pertanyaan \\
\end{tabular} & $\begin{array}{l}- \text { Text } \\
\text { area }\end{array}$ & $\begin{array}{l}\text { Adanya masukan } \\
\text { pada textarea }\end{array}$ & \multirow{4}{*}{$\begin{array}{l}\text { - textbox (6.3) yang } \\
\text { dimasukkan datanya } \\
\text { dengan huruf } \\
\text { - Tidak scroll doun di } \\
\text { halaman beranda } \\
\text { untuk menemukan } \\
\text { produk terbaru (5.1) } \\
\text { - Tidak menekan } \\
\text { tombol panah dan } \\
\text { kiri unt uk } \\
\text { menemulan } \\
\text { keseluruhan produk } \\
\text { terbaru (5.1) } \\
\text { - Tidak menemukan } \\
\text { map yang disediakan } \\
\text { (6.1) } \\
\text { - Tidak mengarahkan } \\
\text { ke produk (7.1) }\end{array}$} \\
\hline 5 & Produk Terbaru & \begin{tabular}{|l|}
5.1 Produk \\
terbaru \\
secara \\
keseluruhan
\end{tabular} & $\begin{array}{l}\text { - Scroll } \\
\text { doun } \\
\text { - Tombol }\end{array}$ & $\begin{array}{l}\text { Melakukan scroll } \\
\text { doun dan } \\
\text { menekan tombol } \\
\text { panah kiri dan } \\
\text { kanan }\end{array}$ & \\
\hline 6 & Map & 6.1 Lokasi & - Map & $\begin{array}{l}\text { Mencari map } \\
\text { pada footer dan } \\
\text { halaman kontak } \\
\text { dan View larger } \\
\text { map }\end{array}$ & \\
\hline 7 & Stok & $\begin{array}{l}7.1 \text { Tersedia } \\
\text { atau tidak }\end{array}$ & $\begin{array}{l}\text { - Link dan } \\
\text { tombol }\end{array}$ & $\begin{array}{l}\text { Mengarahkan } \\
\text { produk dengan } \\
\text { melihat stok ada } \\
\text { dan tanda silang } \\
\text { untuk stok yang } \\
\text { tidak tersedia }\end{array}$ & \\
\hline
\end{tabular}

Tabel I adalah field siap uji yang dapat dilakukan peneliti berdasarkan fitur yang ditentukan. Hasil uji validasi pada setiap fitur, memilki fungsionalitas pada website yang dihasilkan berdasarkan ekspetasi berarti sudah sesuai dengan perancangan kebutuhan yang diinginkan peneliti.

\section{Karakteristik Responden}

Uji usabilitas yang telah lakukan di Dealer Asa Mandiri Motor Yogyakarta pada tanggal 7 hingga 13 April terdapat keseluruhan responden yang berjumlah 50 responden. Karakteristik responden diukur 4 faktor yang terdiri dari tipe pelanggan, usia, pendidikan terakhir dan pengalaman menggunakan sistem basis komputer. dapat dilihat pada Tabel II hingga V.
TABEL II TIPE RESPONDEN

\begin{tabular}{|c|c|c|}
\hline Tipe Responden & Jumlah Responden & Persentase (\%) \\
\hline Pelanggan & 25 & 50 \\
\hline $\begin{array}{c}\text { Non-pelanggan } \\
\text { (masyarakat umum) }\end{array}$ & 23 & 46 \\
\hline Admin & 2 & 4 \\
\hline Total & 50 & 100 \\
\hline
\end{tabular}

TABEL III USIA

\begin{tabular}{|c|c|c|}
\hline Usia & Jumlah Responden & Persentase (\%) \\
\hline$<20$ & 2 & 4 \\
\hline $20-30$ & 33 & 66 \\
\hline $31-40$ & 6 & 12 \\
\hline $41-50$ & 4 & 8 \\
\hline$>51$ & 5 & 10 \\
\hline Total & 50 & 100 \\
\hline
\end{tabular}

TABEL IV PENDIDIKAN TERAKHIR

\begin{tabular}{|c|c|c|}
\hline Pendidikan Terakhir & Jumlah Responden & Persentase (\%) \\
\hline SMP & 2 & 4 \\
\hline SMA & 21 & 42 \\
\hline S1 & 25 & 50 \\
\hline S2 & 2 & 4 \\
\hline Total & 50 & 100 \\
\hline
\end{tabular}

TABEL V PENGALAMAN MENGGUNAKAN SISTEM BERBASIS KOMPUTER

\begin{tabular}{|c|c|c|}
\hline Pengalaman & Jumlah Responden & Persentase $(\%)$ \\
\hline$<1$ Tahun & 5 & 10 \\
\hline $1-2$ Tahun & 13 & 26 \\
\hline$>2$ Tahun & 32 & 64 \\
\hline Total & 50 & 100 \\
\hline
\end{tabular}

\section{Skenario Pengujian}

Skenario pengujian digunakan untuk mengisi kuesioner Webqual 4.0 pada tingkat kinerja (performance). Skenario pengujian dibagi menjadi 9 tugas yang dilakukan responden ialah melihat produk terbaru, melihat produk berdasarkan kategori, menampilkan semua produk dan pilih salah satu produk, melakukan pencarian, membuat komentar baru, membalas komentar, menghubungi admin melalui form hubungi kami, memberikan pertanyaan pada customer service dan mengakses lokasi dealer.

\section{E. Hasil Pengujian Webqual 4.0 dan IPA}

Hasil dari perhitungan skor rata-rata skala likert tingkat kepentingan dan kinerja dapat dilihat pada Tabel VI hingga Tabel XI.

TABEL VI KEPUASAN PENGGUNA BERDASARKAN KATEGORI PADA TINGKAT KEPENTINGAN (IMPORTANCE)

\begin{tabular}{|l|l|l|l|}
\hline Variabel & \multicolumn{1}{|c|}{ Indikator } & Imp & Kategori \\
\hline USA1 & $\begin{array}{l}\text { Kemudahan mempelajari dan } \\
\text { mengoperasikan website }\end{array}$ & 4.34 & Tinggi \\
\hline USA2 & $\begin{array}{l}\text { Kejelasan interaksi pengguna } \\
\text { dengan website }\end{array}$ & 4.38 & Tinggi \\
\hline USA3 & Kemudahan navigasi & 4.3 & Tinggi \\
\hline USA4 & Kemudahan pengguna & 4.46 & Tinggi \\
\hline
\end{tabular}


TABEL VI KEPUASAN PENGGUNA BERDASARKAN KATEGORI PADA TINGKAT KEPENTINGAN (IMPORTANCE LANJUTAN)

\begin{tabular}{|l|l|l|c|}
\hline Variabel & \multicolumn{1}{|c|}{ Indikator } & \multicolumn{1}{c|}{ Imp } & Kategori \\
\hline USA5 & Tampilan website & 4.4 & Tinggi \\
\hline USA6 & Desain website & 4.32 & Tinggi \\
\hline USA7 & Kompetensi website & 4.38 & Tinggi \\
\hline USA8 & Memberikan Pengalaman Positif & 4.46 & Tinggi \\
\hline INF1 & Informasi akurat & 4.44 & Tinggi \\
\hline INF2 & Informasi dapat dipercaya & 4.4 & Tinggi \\
\hline INF3 & Informasi aktual & 4.46 & Tinggi \\
\hline INF4 & Informasi relevan & 4.46 & Tinggi \\
\hline INF5 & Informasi mudah dimengerti & 4.44 & Tinggi \\
\hline INF6 & $\begin{array}{l}\text { Informasi dengan tingkat detail } \\
\text { yang tepat }\end{array}$ & 4.38 & Tinggi \\
\hline INF7 & $\begin{array}{l}\text { Informasi dalam format yang } \\
\text { sesuai }\end{array}$ & 4.42 & Tinggi \\
\hline SERV1 & Reputasi baik & 4.44 & Tinggi \\
\hline SERV2 & Keamanan informasi pribadi & 4.38 & Tinggi \\
\hline SERV3 & Keamanan dalam berinteraksi & 4.36 & Tinggi \\
\hline SERV4 & Ruang personalisasi & 4.34 & Tinggi \\
\hline SERV5 & Rasa komunitas & 4.34 & Tinggi \\
\hline SERV6 & $\begin{array}{l}\text { Kemudahan berkomunikasi } \\
\text { dengan perusahaan }\end{array}$ & 4.28 & Tinggi \\
\hline $\begin{array}{l}\text { SERV7 } \\
\text { Rata-rata }\end{array}$ & Pelaksanaan layanan sesuai janji & 4.36 & $\begin{array}{l}\text { Tinggi } \\
\text { Tinggi }\end{array}$ \\
\hline
\end{tabular}

Pada Tabel VI adalah kepuasan pengguna berdasarkan kategori pada tingkat kepentingan (importance) yang memiliki nilai lebih dari 4.20 yang menandakan setiap indikator berada dikategori tinggi dan rata-rata pada keseluruhan indikator dengan jumlah sebesar 4.388 juga berada dikategori tinggi.

TABEL VII KEPUASAN PENGGUNA BERDASARKAN KATEGORI PADA TINGKAT KINERJA (PERFORMANCE)

\begin{tabular}{|c|c|c|c|}
\hline Variabel & Indikator & Perf & Kategori \\
\hline USA1 & $\begin{array}{l}\text { Kemudahan mempelajari dan } \\
\text { mengoperasikan website }\end{array}$ & 4.3 & Tinggi \\
\hline USA2 & $\begin{array}{l}\text { Kejelasan interaksi pengguna } \\
\text { dengan website }\end{array}$ & 4.3 & Tinggi \\
\hline USA3 & Kemudahan navigasi & 4.36 & Tinggi \\
\hline USA4 & Kemudahan pengguna & 4.32 & Tinggi \\
\hline USA5 & Tampilan website & 4.28 & Tinggi \\
\hline USA6 & Desain website & 4.34 & Tinggi \\
\hline USA7 & Kompetensi website & 4.26 & Tinggi \\
\hline USA8 & $\begin{array}{l}\text { Memberikan Pengalaman } \\
\text { Positif }\end{array}$ & 4.4 & Tinggi \\
\hline INF1 & Informasi akurat & 4.32 & Tinggi \\
\hline INF2 & Informasi dapat dipercaya & 4.16 & Cukup \\
\hline INF3 & Informasi aktual & 4.32 & Tinggi \\
\hline INF4 & Informasi relevan & 4.34 & Tinggi \\
\hline INF5 & Informasi mudah dimengerti & 4.36 & Tinggi \\
\hline INF6 & $\begin{array}{l}\text { Informasi dengan tingkat } \\
\text { detail yang tepat }\end{array}$ & 4.24 & Tinggi \\
\hline INF7 & Informasi format yang sesuai & 4.34 & Tinggi \\
\hline SERV1 & Reputasi baik & 4.42 & Tinggi \\
\hline SERV2 & Keamanan informasi pribadi & 4.2 & Tinggi \\
\hline SERV3 & Keamanan dalam berinteraksi & 4.32 & Tinggi \\
\hline SERV4 & Ruang personalisasi & 4.38 & Tinggi \\
\hline SERV5 & Rasa komunitas & 4.34 & Tinggi \\
\hline SERV6 & $\begin{array}{l}\text { Kemudahan berkomunikasi } \\
\text { dengan perusahaan }\end{array}$ & 4.4 & Tinggi \\
\hline SERV7 & $\begin{array}{l}\text { Pelaksanaan layanan sesuai } \\
\text { janji }\end{array}$ & 4.46 & Tinggi \\
\hline \multicolumn{2}{|l|}{ Rata-rata } & 4.325455 & Tinggi \\
\hline
\end{tabular}

Pada Tabel VII adalah kepuasan pengguna berdasarkan kategori pada tingkat kinerja (performance) yang memiliki nilai lebih dari 4.20 yang menandakan setiap indikator berada dikategori tinggi. Namun, masih ada yang berada dibawah 4.20 pada indikator INF2 yaitu "Informasi dapat dipercaya" dikategorikan cukup tinggi. Rata-rata pada keseluruhan indikator dengan jumlah sebesar 4.325 berada dikategori tinggi.

Kepuasan pengguna berdasarkan kategori tidak termasuk didalam rekomendasi perbaikan. Dikarenakan hasil yang didapatkan berada ditingkat kategori tinggi baik dalam tingkat kepentingan (importance) dan kinerja (performance).

TABEL VIII NILAI RATA-RATA KESELURUHAN INDIKATOR

\begin{tabular}{|c|c|c|c|c|}
\hline Variabel & Indikator & Perf & Imp & GAP \\
\hline USA1 & $\begin{array}{l}\text { Kemudahan } \\
\text { mengoperasikan } \\
\text { website }\end{array}$ & 4.3 & 4.34 & -0.04 \\
\hline USA2 & $\begin{array}{l}\text { Kejelasan interaksi } \\
\text { pengguna pada website }\end{array}$ & 4.3 & 4.38 & -0.08 \\
\hline USA3 & Kemudahan navigasi & 4.36 & 4.3 & 0.06 \\
\hline USA4 & Kemudahan pengguna & 4.32 & 4.46 & -0.14 \\
\hline USA5 & Tampilan website & 4.28 & 4.4 & -0.12 \\
\hline USA6 & Desain website & 4.34 & 4.32 & 0.02 \\
\hline USA7 & Kompetensi website & 4.26 & 4.38 & -0.12 \\
\hline USA8 & $\begin{array}{l}\text { Memberikan } \\
\text { Pengalaman Positif }\end{array}$ & 4.4 & 4.46 & -0.06 \\
\hline INF1 & Informasi akurat & 4.32 & 4.44 & -0.12 \\
\hline INF2 & $\begin{array}{l}\text { Informasi dapat } \\
\text { dipercaya }\end{array}$ & 4.16 & 4.4 & -0.24 \\
\hline INF3 & Informasi aktual & 4.32 & 4.46 & -0.14 \\
\hline INF4 & Informasi relevan & 4.34 & 4.46 & -0.12 \\
\hline INF5 & $\begin{array}{l}\text { Informasi mudah } \\
\text { dimengerti }\end{array}$ & 4.36 & 4.44 & -0.08 \\
\hline INF6 & $\begin{array}{l}\text { Informasi dengan } \\
\text { tingkat detail yang tepat }\end{array}$ & 4.24 & 4.38 & -0.14 \\
\hline INF7 & $\begin{array}{l}\text { Informasi dalam format } \\
\text { yang sesuai }\end{array}$ & 4.34 & 4.42 & -0.08 \\
\hline SERV1 & Reputasi baik & 4.42 & 4.44 & -0.02 \\
\hline SERV2 & $\begin{array}{l}\text { Keamanan dalam } \\
\text { bertransaksi }\end{array}$ & 4.2 & 4.38 & -0.18 \\
\hline SERV3 & $\begin{array}{l}\text { Keamanan informasi } \\
\text { pribadi }\end{array}$ & 4.32 & 4.36 & -0.04 \\
\hline SERV4 & Ruang personalisasi & 4.38 & 4.34 & 0.04 \\
\hline SERV5 & $\begin{array}{l}\text { Pelaksanaan layanan } \\
\text { sesuai janji }\end{array}$ & 4.34 & 4.34 & 0 \\
\hline SERV6 & $\begin{array}{l}\text { Kemudahan } \\
\text { berkomunikasi dengan } \\
\text { perusahaan }\end{array}$ & 4.4 & 4.28 & 0.12 \\
\hline SERV7 & Rasa komunitas & 4.46 & 4.36 & 0.1 \\
\hline \multirow{2}{*}{\multicolumn{2}{|c|}{ Rata-rata }} & 4.32545 & 4.38818 & $\begin{array}{c}- \\
0.0627 \\
\end{array}$ \\
\hline & & 4.32 & 4.39 & -0.07 \\
\hline
\end{tabular}

Pada Tabel VIII adalah hasil rata-rata dari keseluruhan nilai kinerja (performance) dan nilai kepentingan (importance) yang tingkat kepuasannya memilki hasil -0.07 . Tingkat kepuasan pengguna dapat dilihat dari nilai rata-rata keseluruh indikator yang ditandakan dengan nilai positif atau Qi (gap) $\geq 0$. Sebaliknya jika nilai dari rata-rata keseluruhan bernilai Qi (gap) $\leq 0$ atau bernilai negatif, maka tingkat kepuasan pengguna masih belum tercapai. 
TABEL IX NILAI KESENJANGAN (GAP) DIMENSI USABILITY

\begin{tabular}{|l|l|c|c|c|}
\hline Variabel & \multicolumn{1}{|c|}{ Indikator } & Perf & Imp & GAP \\
\hline USA1 & $\begin{array}{l}\text { Kemudahan mempelajari } \\
\text { dan mengoperasikan } \\
\text { website }\end{array}$ & 4.3 & 4.34 & -0.04 \\
\hline USA2 & $\begin{array}{l}\text { Kejelasan interaksi } \\
\text { pengguna dengan website }\end{array}$ & 4.3 & 4.38 & -0.08 \\
\hline USA3 & Kemudahan navigasi & 4.36 & 4.3 & 0.06 \\
\hline USA4 & Kemudahan pengguna & 4.32 & 4.46 & -0.14 \\
\hline USA5 & Tampilan website & 4.28 & 4.4 & -0.12 \\
\hline USA6 & Desain website & 4.34 & 4.32 & 0.02 \\
\hline USA7 & Kompetensi website & 4.26 & 4.38 & -0.12 \\
\hline USA8 & $\begin{array}{l}\text { Memberikan Pengalaman } \\
\text { Positif }\end{array}$ & 4.4 & 4.46 & -0.06 \\
\hline RATA-RATA & 4.32 & 4.38 & -0.06 \\
\hline
\end{tabular}

Pada Tabel IX adalah menunjukkan nilai kesenjangan (gap) dimensi usability. Berdasarkan hasil rata-rata yang didapatkan dari selisih antara nilai kinerja (Performance) dan nilai kepentingan (Importance) bernilai negatif yaitu 0.06. Indikator yang paling banyak memiliki nilai kesenjangan pada dimensi usability terdapat pada variabel USA4 (Kemudahan pengguna) sebesar -0.14.

\section{TABEL X NILAI KESENJANGAN (GAP) DIMENSI INFORMATION} QUALITY

\begin{tabular}{|l|l|c|c|c|}
\hline Variabel & \multicolumn{1}{|c|}{ Indikator } & Perf & Imp & GAP \\
\hline INF1 & Informasi akurat & 4.32 & 4.44 & -0.12 \\
\hline INF2 & Informasi dapat dipercaya & 4.16 & 4.4 & -0.24 \\
\hline INF3 & Informasi aktual & 4.32 & 4.46 & -0.14 \\
\hline INF4 & Informasi relevan & 4.34 & 4.46 & -0.12 \\
\hline INF5 & Informasi mudah dimengerti & 4.36 & 4.44 & -0.08 \\
\hline INF6 & $\begin{array}{l}\text { Informasi dengan tingkat } \\
\text { detail yang tepat }\end{array}$ & 4.24 & 4.38 & -0.14 \\
\hline INF7 & $\begin{array}{l}\text { Informasi dalam format yang } \\
\text { sesuai }\end{array}$ & 4.34 & 4.42 & -0.08 \\
\hline Rata-rata & & 4.3 & 4.43 & -0.13 \\
\hline
\end{tabular}

Pada Tabel $\mathrm{X}$ adalah menunjukkan nilai kesenjangan (gap) dimensi information quality. Berdasarkan hasil ratarata yang didapatkan sebesar -0.13. Indikator yang paling banyak memilki nilai kesenjangan pada dimensi information quality terdapat pada variabel INF2 (Informasi dapat dipercaya) sebesar -0.24 .

\section{TABEL XI NILAI KESENJANGAN (GAP) DIMENSI SERVICE} INTERACTION

\begin{tabular}{|l|l|l|l|l|}
\hline Variabel & \multicolumn{1}{|c|}{ Indikator } & \multicolumn{1}{c|}{ Perf } & \multicolumn{1}{c|}{ Imp } & \multicolumn{1}{c|}{ GAP } \\
\hline SERV1 & Reputasi baik & 4.42 & 4.44 & -0.02 \\
\hline SERV2 & $\begin{array}{l}\text { Keamanan informasi } \\
\text { pribadi }\end{array}$ & 4.2 & 4.38 & -0.18 \\
\hline SERV3 & Keamanan berinteraksi & 4.32 & 4.36 & -0.04 \\
\hline SERV4 & Ruang personalisasi & 4.38 & 4.34 & 0.04 \\
\hline SERV5 & Rasa komunitas & 4.34 & 4.34 & 0 \\
\hline SERV6 & $\begin{array}{l}\text { Kemudahan berkomunikasi } \\
\text { dengan perusahaan }\end{array}$ & 4.4 & 4.28 & 0.12 \\
\hline SERV7 & $\begin{array}{l}\text { Pelaksanaan layanan sesuai } \\
\text { janji }\end{array}$ & 4.46 & 4.36 & 0.1 \\
\hline \multirow{2}{*}{ Rata-rata } & \multicolumn{2}{|l}{} \\
\cline { 2 - 5 } & 4.36 & $\begin{array}{l}4.357 \\
143\end{array}$ & $\begin{array}{l}0.002 \\
857\end{array}$ \\
\cline { 2 - 5 } & 4.36 & 4.357 & 0.003 \\
\hline
\end{tabular}

Pada Tabel XI adalah menunjukkan nilai kesenjangan (gap) dimensi service interaction. Berdasarkan hasil ratarata yang didapatkan sebesar 0.003 . Indikator yang paling banyak memiliki nilai kesenjangan pada dimensi service interaction terdapat pada variabel SERV2 (Keamanan dalam berinteraksi) sebesar -0.18 .

Hasil dari kuadran matriks analisis ImportancePerformance Analysis (IPA) berdasarkan letak kuadran setiap indikator yang menggunakan hasil rata-rata keseluruhan pada Tabel VIII. Kuadran matriks analisis dapat dilihat pada gambar 6.

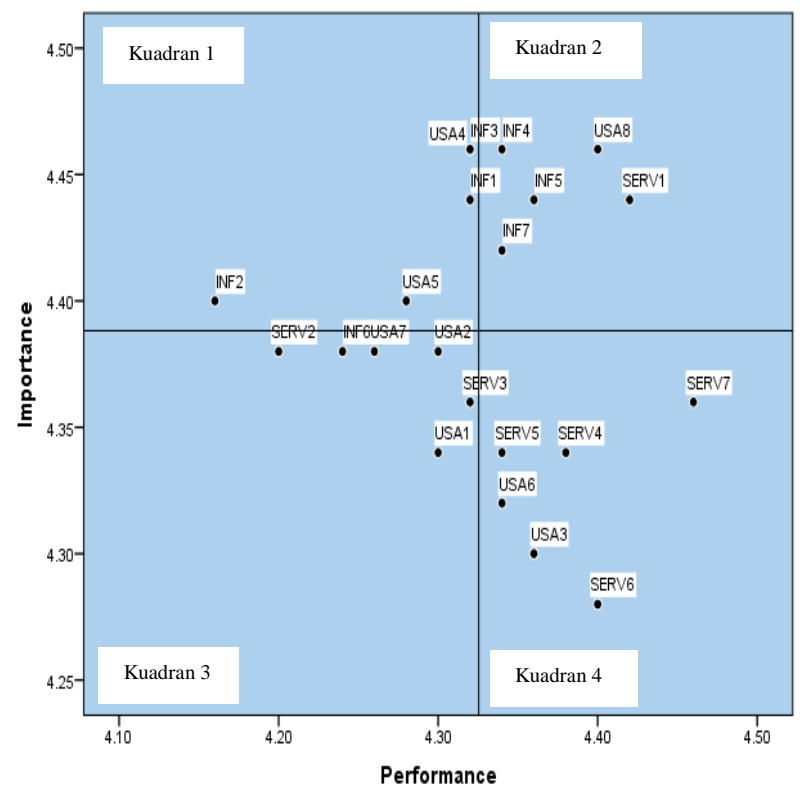

Gambar 6. Diagram Matriks Importance-Performance Analysis (IPA)

Berdasarkan diagram matriks Importance-Performance Analysis (IPA) pada Gambar 6 adalah kedudukan setiap indikator. Posisi setiap indikator dapat disimpulkan bahwa indikator INF1, INF2, INF3, USA4, dan USA5 yang terdapat pada kuadran 1 adalah indikator yang belum sesuai dengan dengan harapan pengguna dikarenakan memiliki nilai tingkat kepentingan yang tinggi namun tingkat kinerja rendah sehingga indikator dalam kuadran 1 merupakan faktor utama pada perbaikan.

TABEL XII ACUAN HASIL DARI SARAN PENGEMBANGAN

\begin{tabular}{|c|l|l|l|}
\hline \multirow{2}{*}{ R } & \multicolumn{2}{|c|}{ Tipe Responden } & \multicolumn{2}{c|}{ Indikator Terkait } \\
\cline { 3 - 4 } & & \multicolumn{1}{c|}{-} \\
\hline 4 & Non-Pelanggan & USA2 & USA3, USA4 \\
\hline 7 & Non-Pelanggan & - & USA5 \\
\hline 9 & Non-Pelanggan & - & USA5, SERV5 \\
\hline 10 & Non-Pelanggan & - & INF5, USA5 \\
\hline 23 & Pelanggan & USA5 & USA5 \\
\hline
\end{tabular}

Pada Tabel XII menunjukkan beberapa saran pengembangan yang sangat berpengaruh untuk mengetahui bagian indikator yang masih harus dikembangkan lagi pada hasil rekomendasi perbaikan. Huruf " $R$ " diartikan sebagai 
urutan responden, simbol "+" diartikan sebagai pujian atau masukan positif dari responden, dan simbol "_" diartikan sebagai kritik atau masukan negatif dari responden.

\section{F. Analisa Hasil Keseluruhan}

Terdapatnya selisih nilai kinerja dan kepentingan menunjukkan adanya kesenjangan yang terjadi. Hasil dari keseluruhan indikator memiliki nilai negatif sebesar -0.07 yang cenderung relatif kecil. Namun, menunjukkan bahwa nilai kinerja (Performance) yang dirasakan belum memenuhi nilai kepentingan (Importance) yang diharapkan pengguna. Adapun indikator-indikator yang memilki nilai kesenjangan terbesar berdasarkan dimensi usability adalah "Kemudahan Pengguna" berdasarkan kuesioner yang dibuat peneliti kemudahan pengguna diartikan "Website mudah untuk digunakan berdasarkan menu pencarian" dengan nilai kesenjangan (gap) sebesar -0.14, dimensi information quality adalah "Informasi dapat dipercaya" dengan nilai kesenjangan sebesar -0.24 , dan dimensi service interaction adalah "Keamanan informasi pribadi" dengan nilai kesenjangan (gap) sebesar -0.18. Hasil dari grafik matriks akan dibedakan menjadi 4 kuadran yaitu:

1. Kuadran 1: INF2 yaitu "Informasi dapat dipercaya", USA4 yaitu "Kemudahan pengguna", INF3 yaitu "Informasi aktual", INF1 yaitu "Informasi akurat", dan USA5 yaitu "Tampilan Website". Pada kuadran 1 terdapat 3 indikator yang masih belum sesuai dengan keinginan pengguna sehingga dijadikan sebagai prioritas utama perbaikan.

2. Kuadran 2: INF4 yaitu "Informasi relevan", INF7 yaitu "Informasi dalam format yang sesuai", INF5 yaitu "Informasi mudah dimengerti", USA8 yaitu "Memberikan pengalaman positif", dan SERV1 yaitu "Reputasi baik". Pada kuadran 2 beberapa indikator sudah sesuai dengan keinginan penggunadan harus dipertahankan kedudukan indikatornya.

3. Kuadran 3: SERV2 yaitu "Keamanan informasi", INF6 yaitu "Informasi dengan tingkat detail yang tepat", USA7 yaitu "Kompetensi website", USA2 yaitu "Kejelasan interaksi pengguna dengan website", SERV3 yaitu "Keamanan dalam berinteraksi", dan USA1 yaitu "Kemudahan dalam mempelajari dan mengoperasikan website". Pada kuadran 3 indikator-indikator tidak dianggap penting untuk dikembangkan dikarenakan memiliki nilai kepentingan (importance) yang rendah dan nilai kinerja (performance) yang rendah juga.

4. Kuadran 4: SERV5 yaitu "Rasa komunitas", SERV4 yaitu "Ruang personalisasi", USA6 yaitu "Desain website", USA3 yaitu "Kemudahan navigasi", SERV6 yaitu "Kemudahan berkomunikasi dengan perusahaan", dan SERV7 yaitu "Pelaksanaan layanan sesuai janji". Pada kuadran ini indikator-indikator dianggap sudah sangat sesuai keinginan pengguna sehingga tidak terlalu banyak untuk diperhatikan karena nilai dari kepentingan (importance) lebih rendah daripada nilai kinerja (performance).

\section{G. Permasalahan Pada Proses Pengujian}

Penulis mendapatkan hasil bias pada kuesioner yang dapat dilihat dari nilai keseluruhan yang termasuk relatif kecil namun sebenarnya kebanyakan responden atau pembeli masih kurang menguasai penggunaan sistem berupa website dan tidak mengerti dari pernyataan-pernyataan yang disediakan pada metode Webqual 4.0. Faktor lain yang dianggap penyebab memiliki nilai bias ialah saran pengembangan yang kebanyakan diluar dari kuadran 1 (INF1, INF2, INF3, USA4, dan USA5) seperti ruang untuk komunitas (SERV5) yang memilki banyak saran dari responden mengenai diskusi antar pembeli yang masih menggunakan email dalam textbox (username).

\section{H. Hasil dan Analisa Skenario Pengujian}

Hasil dari skenario pengujian ini didapatkan dari 15 responden yang melakukan pengujian. Kebanyakan dari non-pelanggan yang dapat melakukan pengujian ini dikarenakan peneliti hanya memiliki beberapa kontak dari pelanggan-pelanggan yang telah diberikan kuesioner dan penulis juga melakukan pengujian kembali kepada nonpelanggan dikarenakan belum ada hasil screen recording. Kuesioner berupa form online merupakan salah satu penyebab peneliti tidak dapat melakukan screen recording. Oleh karena itu, penulis melakukan pengujian kembali kepada 15 responden untuk mendapatkan screen recording yang digunakan untuk mengetahui nilai dari evaluasi waktu yang dilakukan oleh responden.

1. Evaluasi Waktu: Evaluasi waktu pada skenario pengujian didapatkan dari responden yang telah ditentukan sebanyak 15 responden. Evaluasi ini didapat melalui 15 responden yang dipilih berdasarkan tipe pelanggan yaitu pelanggan (5 responden) dan non-pelanggan (10 responden). Adapun rata-rata waktu tercepat terdapat pada tugas ke-2 (memilih produk berdasarkan kategori produk) dan waktu terlama terdapat pada tugas ke-7 (menghubungi admin melalui form hubungi kami). Hasil kategori gagal terhadap tugas yang dilakukan responden disebabkan oleh beberapa jenis kesalahan seperti responden mengisi textbox username dengan mengisi komentar yang seharusnya responden mengisinya pada textarea (tulis komentar), responden tidak mengisi textbox nomor handphone, responden gagal dalam menemukan produk terbaru dan responden tidak mengisi tugas yang seharusnya dilakukan. Namun dari beberapa kesalahan yang dilakukan, responden dapat memperbaiki kesalahannya dengan mengulang tugas yang dilakukan.

\section{Hasil Rekomendasi Perbaikan}

Berdasarkan dari hasil data grafik matriks Importance Performance Analysis (IPA) didapatkan prioritas utama pada kuadran 1 dalam rekomendasi perbaikan dari pengguna. Variabel-variabel yang menjadi prioritas utama yaitu: 
1. INF1 (Informasi akurat) dan INF3 (Informasi actual): Informasi akurat dan aktual tidak ada masukan pada form yang disediakan pada kuesioner. Namun, penulis mendapatkan informasi secara lisan dari beberapa responden mengenai kurang updatenya stok yang disediakan pada dealer. Ketika responden datang ke dealer, mereka tidak menemukan motor yang tersedia pada website. Kesalahan ini terdapat pada pengelolaan admin yang kurang update pada stok yang tersedia ataupun tidak tersedia. Dari saran ini dapat diartikan bahwa nilai dari INF1 (Informasi akurat) adalah stok motor yang tidak sesuai dari website dengan dealer dan INF3 (Informasi aktual) adalah kurangnya update pada stok motor sehingga pengguna tidak merasa puas dengan hasil informasi yang didapatkan pada dealer.

2. INF2 (Informasi dapat dipercaya): Hasil dari data kuesioner, terdapat beberapa responden yang kurang setuju dengan kinerja pada website dalam indikator ini. Adapun responden yang menambahkan saran secara lisan ke penulis "Mungkin bisa menampilkan prosedur alur penjualan yang disediakan dealer Asa Mandiri Motor ditampilkan pada slider halaman awal" (R.9). Perbaikan dapat dilihat pada Gambar 7.

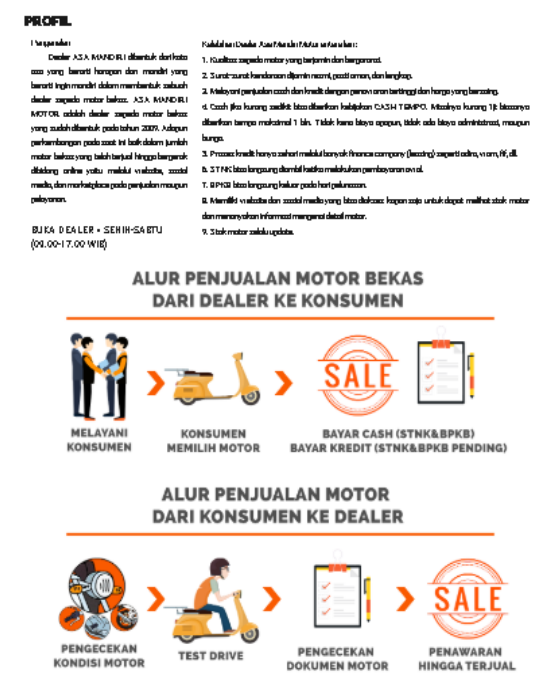

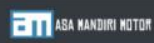

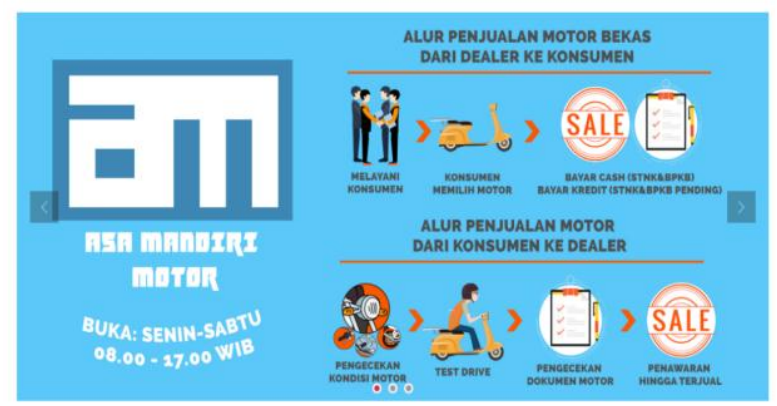

Gambar 7. Tampilan Prosedur Penjualan Motor Sebelum dan Sesudah
3. USA4 (Kemudahan pengguna): Hasil dari data kuesioner, mengenai USA4 (Kemudahan pengguna) masih ada beberapa yang kurang setuju dikarenakan susahnya pengguna dalam menemukan masukan pencarian yang hanya dapat ditemukan pada halaman kategori, semua produk, dan pencarian yang tidak ada produknya menghasilkan tampilkan berupa halaman kosong. Adapun responden yang meninggalkan saran "Pencarian yang tidak ada produknya ditampilkan kosong" (R.4). Salah satunya perbaikan ini dapat dilihat pada Gambar 8 .

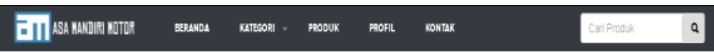

TIDAK ADA PRODUK YANG DITEMUKAN:

\section{Gambar 8. Tampilan Pencarian Tidak Ada Produk}

4. USA5 (Tampilan website): Hasil dari data kuesioner, mengenai USA5 (Tampilan website) masih ada beberapa yang harus diperbaiki. Perbaikan-perbaikan dalam indikator ini ialah form hubungi kami ditampilkan pada footer, menu contact dan home dijadikan menjadi kontak dan beranda karena menu yang lainnya menggunakan bahasa Indonesia, dan membuat lokasi peta dealer berada di footer setiap halaman terkecuali halaman kontak. Saran pengembangan mengenai indikator ini terdapat di beberapa responden yang menyebutkan "Namun, sayangnya tidak ditampilkannya form hubungi kami pada catatan bawah pada website" (R.23), "menu yang lain menggunakan bahasa Indonesia" (R.10), dan "mapnya lokasi kebanyakan website letaknya di footer tiap page" (R..7). Salah satu perbaikan ini dapat dilihat pada Gambar 9.

\begin{tabular}{|l|llll|}
\hline HOME & KATEGORI & PRODUK & PROFIL & CONTACT \\
\hline BERANDA & & & & \\
\hline
\end{tabular}

Gambar 9. Tampilan Menu Contact dan Home Menjadi Kontak dan Beranda

5. Berdasarkan komentar terbanyak: Adapun hasil dari komentar yang paling banyak yaitu tidak perlunya menggunakan email ketika membalas komentar sebelumnya. Perubahan ini telah dilakukan peneliti dengan melakukan perubahan balasan pengguna yang sebelumnya menggunakan email dan diganti menjadi username.

\section{KESIMPULAN}

Berdasarkan hasil analisa dan pembahasan serta hasil dari simulasi sistem dapat disimpulkan sebagai berikut:

1. Fungsionalitas pada website berdasarkan pengujian black box testing sudah sesuai dengan perancangan kebutuhan. 
Website telah dikembangkan pada dealer Asa Mandiri Motor dengan pendekatan Waterfall. Website dapat diakses pada alamat https://asamandirimotor.com.

2. Berdasarkan uji Webqual 4.0 dan Importance Performance Analysis (IPA) didapatkan nilai kesenjangan -0.07 yang memiliki arti website belum sesuai dengan keinginan pengguna yang relatif kecil.

3. Prioritas utama yang dapat dijadikan perbaikan sistem berada pada kuadran 1. Indikator-indikator yang berada di kuadran 1 ialah informasi akurat (INF1), informasi dapat dipercaya (INF2), informasi aktual (INF3), mudah digunakan (USA4) dan tampilan menarik (USA5). Peneliti telah melakukan perbaikan website Dealer Asa Mandiri Motor.

4. Terdapatnya nilai bias dikarenakan hasil yang didapatkan berada pada relatif kecil tetapi sebenarnya kebanyakan responden atau pembeli masih kurang menguasai penggunaan sistem berupa website, tidak mengerti dari pernyataan-pernyataan yang disediakan pada metode Webqual 4.0 dan saran pengembangan yang banyak diluar dari kuadran 1 seperti ruang untuk komunitas (SERV5).

Diharapkan setelah dilakukannya penelitian ini dapat dikembangkannya website Asa Mandiri Motor dengan memperhatikan:

1. Website Asa Mandiri Motor dapat terlihat bagus tampilannya ketika berada di resolusi layer 1280x800 pixel yang merupakan layar monitor komputer yang berukuran sedang. Sarannya dapat untuk mengatur resolusi pada responsif smartphone sehingga dapat membuat pengguna lebih mudah dan nyaman untuk diakses.

2. Setelah melakukan pengujian berdasarkan metode Webqual 4.0 dan Importance Performance Analysis (IPA) didapatkannya nilai kesenjangan dan peneliti sudah melakukan perbaikan pada beberapa indikator yang belum sesuai dengan keinginan pengguna. Namun, belum dilakukannya pengujian lanjutan. Diharapkan untuk penelitian selanjutnya dapat melakukan pengujian lanjutan untuk mengetahui hasil tingkat kualitas website
Asa Mandiri Motor, rekomendasi perbaikan yang harus dilakukan dan menentukan hasil dari karakteristik responden berdasarkan jenis kelamin.

\section{DAFTAR PUSTAKA}

[1] Romadhoni, E. N., Widyaningtyas, T., \& Pujianto, U. IMPLEMENTASI MODEL WATERFALL PADA PENGEMBANGAN SISTEM INFORMASI ALUMNI SMKN 1 JENANGAN PONOROGO . Seminar Nasional Sistem Informasi Indonesia, pp. 445-452, 2015.

[2] Adewono, A. A., \& Adewono, B. A. Software Engineering Methodologies: A Review of the Waterfall Model and ObjectOriented Approach. International Journal of Scientific \& Engineering Research, pp. 427-434, 2013.

[3] Santoso, B. S., \& Anwar, M. F. Analisis Kualitas Website Menggunakan Metode Webqual Dan Importance - Performance Analysis (IPA) Pada Situs Kaskus. National Conference on Information Technology and Technical Engineering (CITEE), 2015.

[4] Sommervile, I. Software Engineering Ninth Edition. Boston: Pearson Education, 2011.

[5] Pressman. Software Engineering: A Practitioner's Approach Eighth Edition. New York: Raghothaman Srinivasan, 2014.

[6] Mustaqbal, M. S., Firdaus, R. F., \& Rahmadi, H. PENGUJIAN APLIKASI MENGGUNAKAN BLACK BOX TESTING BOUNDARY VALUE ANALYSIS . Jurnal Ilmiah Teknologi Informasi Terapa, pp. 31-36, 2015.

[7] Pressman. Rekayasa Perangkat Lunak Pendekatan Praktisi Buku (2nd ed., Vol. I). (L. Harnaningrum, Trans.) Yogyakarta, Yogyakarta, Indonesia: Penerbit Andi \& McGraw-Hill Book Co, 2002.

[8] Prabowo, Y., Sulistiowati, \& Lemantara, J. Analisis Pengaruh Kualitas Website Terhadap Kepuasan Pengguna Berdasarkan Metode Webqual 4.0 Pada Website Hotel 88. JSIKA, pp. 1-6, 2016.

[9] Syaifullah, \& Soemantri, D. O. PENGUKURAN KUALITAS WEBSITE MENGGUNAKAN METODE WEBQUAL 4.0 . Jurnal Rekayasa dan Manajemen Sistem Informasi, pp. 19-25, 2016.

[10] Huang, Y.-K., Wei-Shang, Fan, Tsai, M.-C., \& Ho, Y.-H. Using Importance-Performance Analysis in Evaluating Taiwan Blog eService Quality. Journal of Economics, Business and Management, pp. 338-345, 2015.

[11] Azizah, E. C., Aryadita, H., \& Herlambang, A. D. Evaluasi Kualitas Website Forum Diskusi Online Menggunakan Metode Webqual 4.0 dan Importance Performance Analysis (Studi Kasus Pada Website Dictio). Jurnal Pengembangan Teknologi Informasi dan Ilmu Komputer, pp. 2549-2559, 2018.

[12] Sugiyono. Metode Penelitian Pendidikan Pendekatan Kuantitatif, Kualitatif Dan R\&D. Bandung: ALFABETA, 2010 